Original Research Paper

\title{
Investigating the Effects of Landfill in Azad-Shahr City on the Physicochemical Properties of Groundwater
}

\author{
${ }^{1}$ Sara Abdollahi, ${ }^{2}$ Safieh Javadinejad, ${ }^{3}$ Kaveh Ostad-Ali-Askari and ${ }^{4}$ Vijay P. Singh \\ ${ }^{I}$ Department of Environmental Science, Faculty of Natural Resources and Desert Studies, Yazd University, Yazd, Iran \\ ${ }^{2}$ Department of Water Engineering, University of Birmingham, Edgbaston St, B152TT, UK \\ ${ }^{3}$ Department of Civil Engineering, Najafabad Branch, Islamic Azad University, Najafabad, Iran \\ ${ }^{4}$ Department of Biological and Agricultural Engineering and Zachry, Department of Civil Engineering, \\ Texas A and M University,321 Scoates Hall, 2117 TAMU, College Station, Texas 77843-2117, USA
}

Article history

Received: 02-03-2019

Revised: 05-05-2019

Accepted: 31-05-2019

Corresponding Author:

Kaveh Ostad-Ali-Askari

Department of Civil

Engineering, Najafabad Branch, Islamic Azad University,

Najafabad, Iran

Email: kaveh.oaa2000@gmail.com

\section{Introduction}

Recently, the need for water in microorganisms in many ways is known as a serious problem because many of the water resources in the world have reached a critical point. The non-sanitary municipal, industrial and hospital burial is considered as one of the environmental problems of the country. In our country (IRAN), only $8 \%$ of municipal waste got recycled and compost and $92 \%$ of waste are buried (Badou, 2000). Landfill sites have been identified as one of the major threats to underground water

\begin{abstract}
Locations near landfills have a lot of potential for contamination of groundwater, because there is a high potential for contamination with emulsion in these areas. In this study, the quality of physic chemical and carbon-organic materials (TOC) of water wells around landfill of AzadShahr city was investigated. To accomplish this purpose, sampling of water from seven deep wells around the landfill site (upstream and downstream of the burial site) was carried out in the spring and summer of 2017. Then, its physicochemical parameters such as Electrical Conductivity (EC), temperature, Potential of Hydrogen (PH), chlorine, Total Dissolved Solids (TDS) and hardness were measured by standard methods. Total Dissolved Solids (TDS) is a quantity of the soluble composed quantity of all inorganic and organic substances present in a liquid in molecular, ionized or microgranular (colloidal sol) suspended form. Electrical Conductivity (EC) is a computation of the dissolved material in an aqueous solution, which relates to the capability of the material to treatment electrical current through it. PH (Potential of Hydrogen) is a quantity of the acidity of the water or soil depend on its hydrogen ion condensation and is mathematically determined as the negative logarithm of the hydrogen ion condensation. Based on the results of TDS, chlorine, hardness, water content of wells around landfill were $719 \pm 21,62 \pm 19,333 \pm 73$ (mg.l) and electrical conductivity was $1440 \pm 120(\mu \mathrm{m} . \mathrm{cm})$, respectively. Temperature and $\mathrm{PH}$ were $19.5 \pm 0.5$ and $7.1 \pm 0.15$ and TOC was $238 \pm 240$ (mg.l), respectively. Also, the results showed that the concentration of physicochemical parameters of water wells around landfill is below the standard level of the drinking water of the country and the concentration of all the quality parameters in lower wells was measured more than high wells. Except for the hardness parameter, there was no significant relationship with other parameters.
\end{abstract}

Keywords: Landfill, Hardness, Physico-Chemical, Electrical Conductivity 
environmental policies (European Commission 1999) and the National Legislation, the pollution of the underground water by means of solid waste in the landfill is known as a major economic, social and environmental issue in many European countries. Since Iran is located in the dry and semi-arid region of the world and has an annual rainfall of 250 millimeters with spatial and temporal dispersal distribution, which is about one-third of the world's annual rainfall, the importance of these water resources is heightened. In Iran, more than $52 \%$ of the water requirement is met through sub-surface water (Hasheminezhad and Karimi, 2006; Abedi Kopae, 2001). Since groundwater movement is very slow, after the onset of contamination, years must be passed in order for the water to be affected and polluted in the well. If groundwater is polluted, it will be more difficult to observe the pollution and therefore the concern is even more. Eliminating the pollution of an aquifer is time-consuming and difficult and can never be fully performed. On this basis, it took many years for a contaminated water layer, after removing the source of contamination, to be returned to its first state. If no serious action happens in this regard, the quality of groundwater will be getting worse (Pishkar Dehkordi, 2004). Landfill production and management in landfill sites is one of the most important environmental issues in landfill sites. The most important environmental impacts of landfill sites are surface and groundwater contamination. The emulsion of landfill sites is due to the melting of the water, the moisture present in the waste and the biological degradation of the waste. Humidity penetrating into the waste site flows into waste and is directed to the waste disposal center. Due to the passage of emulsion among the waste, the emulsion of landfill sites contains various organic and chemical compounds (Zoghi and Ghavidel, 2010). New landfills are more polluted than old ones and have a lower PH. Therefore, it can be said that the composition of the emulsion depends on how old the landfill site is. For example, if acidic phase is sampled from the landfill site, $\mathrm{pH}$ is acidic and the amount of BOD5, COD, TOC, nutrients and heavy metals will be high (Kreith and Tchobanoglous, 2002). So far, several studies have focused on the effects of landfill sites. The effect of the landfills on the quality of underground water in Mashhad has been investigated by Abedi Kupai. The results showed that the water quality of the downstream wells, considering some parameters, was lower than the standard (Abedi Kopae, 2001). Underground water pollution, even in advanced countries, has caused environmental degradation and high costs to eliminate pollution. Pollution in the underground water table caused by the Borden landfill in Canada caused a spatial pollution of $700 \mathrm{~m}$, a width of $600 \mathrm{~m}$ and a depth of $20 \mathrm{~m}$. Also, the Bavarian landfill in Germany (about $300 \mathrm{~m}$ in length) has contaminated the soil. The contamination of the landfill in Denmark has also contaminated areas of $40 \mathrm{~m}$ and a maximum depth of $20 \mathrm{~m}$ in the groundwater table, which will take several years to eliminate this contamination in addition to the high cost of the process (Shariat Panahi, 1998; Dehkordi, 2004). Therefore, it is necessary for the water source to be exploited reasonably and protected against pollution. In particular, groundwater contamination is far more important than surface water pollution because the interval between the onsets of contamination of the sub surface water and its occurrence sometimes lasts up to several years. Therefore, it is very costly and time-consuming to find the source of pollution and eliminate it (Filipic, 1995).

\section{Important Parameters of Underground Water Quality}

In general, underground water is subject to pollution just like the surface water; flood, sewage, industrial and agricultural sewage can contaminate them. Encountering low or severe rainfall can easily transfer various plant, animal and even industrial and toxic particle by which the water is heavily contaminated. Underground waters just like surface water have different variables such as Coliform, bacteria, low turbidity, variable flavor, variable odor, low to high soluble solids, variable radioactivity, variable soluble oxygen and carbon dioxide. The concept of these variations and qualitative fluctuations is that they need to be treated before they are consumed. Further important qualitative water parameters are mentioned in the following part (Sládecek, 1973).

\section{Water Temperature}

Water temperature is mostly due to the absorption of solar energy by water and also the absorption by air and surrounding soil. Certainly, this is not the case with human activities happening around this water source, because in this situation, usually drainage water from various industries and in particular cooling towers, can increase the temperature of the receiving water. It is usually necessary in water quality studies to measure water temperature and, finally, a pattern or design for the temperature change of the water source to be obtained throughout the year, because the water temperature can be highly effective on the population and the type of aquatic species in the water (Voutchkov, 2014).

\section{Total Soluble Solids (T.D.S)}

Total soluble solids, including total substances that are soluble in water, but not including suspended sediments, soluble colloids and gases. If all the watersoluble solids are precisely determined by chemical test, the total sum of them is equal to (T.D.S) in milligrams per liter (PPM). Total water soluble solids can be calculated with two methods. In the first method, heat one liter of water at $180^{\circ} \mathrm{C}$ or between $105^{\circ} \mathrm{C}$ and $110^{\circ} \mathrm{C}$ to evaporate. With this action, the remaining solids are obtained. In the second method, the sum of all water ions in a liter is calculated (Osilan, 2016). 
Table 1: Classification of groundwater by total soluble solids (T.D.S) (Osilan, 2016)

\begin{tabular}{ll}
\hline T.D.S $<1000 \mathrm{ppm}$ & Freshwater \\
\hline $1000<$ T.D.S $<3000 \mathrm{ppm}$ & Water with medium salt \\
$10000<$ T.D.S $<35000 \mathrm{ppm}$ & Salty water \\
\hline
\end{tabular}

Table 1 shows Categorization of groundwater by total soluble solids and it displays various T.D.S such as (1000 $<$ T.D.S $<3000$ ppm; $10000<$ T.D.S $<35000$ ppm) regard to Freshwater condition. It depends on Water with medium salt and Salty water, Respectively (Osilan, 2016).

\section{Electrical Conductivity}

The electrical conductivity of the water represents the ionic strength of a solution for the transfer of electric current. Electric conductivity is the opposite of electrical resistance and its unit is mho. Electrical conductivity variations as well as electrical resistance depend entirely on temperature. Therefore, measurements are carried out at a standard temperature, which is generally $25^{\circ} \mathrm{C}$ (Burton and Robert Pitt, 2014).

\section{Water Hardness}

The water hardness is mainly due to calcium and magnesium salts. Other water-soluble metals such as iron, copper, zinc and lead can affect water hardness, but due to the very small amounts of these metals in natural waters, they are not considered in the calculation of water hardness. The degree of hardness is based on the concentration of calcium carbonate $\left(\mathrm{CaCO}_{3}\right)$ (Boyd and Tucker, 2014).

\section{Alkalinity and Acidity of Water}

The presence of bicarbonate ions in water is known as alkalinity. Carbonate ions increase the water tampon property and confront the changes in water acidity that occurs the day. Bases usually react with hydrogen ion. Therefore, any substance that reacts with hydrogen ion is related to alkaline (Borden and Yanoschak, 1990). In recent years, numerous studies have been carried out on the effects of landfills on underground water resources and various results have been obtained. Bordeaux and Yannoschak investigated the surface water and groundwater resources of 71 landfills in North Carolina. The results of this study showed that concentrations of TDS, TOC, $\mathrm{Zn}$ and $\mathrm{Pb}$ in water resources have increased significantly (Sholichin, 2012). Sholichin studied the pollution of underground water by landfill of Melange in Indonesia. In this study, according to laboratory tests on the water samples, $\mathrm{BOD}, \mathrm{COD}, \mathrm{PH}, \mathrm{NO}_{3}$ and $\mathrm{EC}$ were 7.5, 32, 10.8, 0.09 (mg.l) and 461 micro scales, respectively that all of them are above the water quality standards. The results of this study showed that surface water, underground water and water in the wells adjacent to the landfill were contaminated by the landfills (Nasrabadi and Maedeh, 2014). Nasrabadi and
Maedeh (2014) reviewed the quality index in the capital city of Tehran. It was observed that the water quality in 2012 was lower than the water quality in 2011, as well as the value of the index in the eastern and southern parts of Tehran in comparison with sampling units, reflecting the lower quality of water in these areas (Jamshidi et al., 2014). Jamshidi et al. (2014) reviewed the effect of landfill sites in Yasuj on the quality of the downstream water source (Well No. 6, Tangkenare). The results showed that in all samples of well water No. 6, except for the total hardness and lead ion, the values of other parameters were less than the desired level (Eaton and Franson, 2005).

\section{Materials and Methods}

\section{Introducing the Region}

Azadshahr city is one of the cities of Golestan province with an area of $852 \mathrm{Km}^{2}$. The city population in 2015 was 96803 people, with a distance of 75 kilometers from the provincial capital and $150 \mathrm{~m}$ above sea level between $55^{\circ} \mathrm{C}, 4 \mathrm{~min}$ to $55^{\circ} \mathrm{C}, 38$ min east and $36^{\circ} \mathrm{C}, 48$ min to $37^{\circ} \mathrm{C}$ and $12 \mathrm{~min}$ the northern latitude is located in the east of Golestan province (Fig. 1 and 2). The lifetime of the waste deposit location is about 6 years. Due to the lack of mechanization of the waste collection system, the amount of daily input of waste to the site is not recorded. The geographic coordinates of the wells investigated in Table 2 .

\section{Sampling Method}

In this research, in order to study the physicochemical parameters (Table 3) and carbon-organic substances (TOC) in underground water resources around the landfill site of Azadshahr city, according to the general slope of the area, sampling of water from 7 wells of drinking water and agricultural water in exploitation of upstream and downstream landfills was carried out and was considered as a statistical society. Sampling was conducted in spring and summer of 2017 for each season. Physicochemical parameters such as EC, temperature, $\mathrm{PH}$, chlorine and hardness in the upper and lower end of the landfill with the standard methods mentioned in the book of standard methods for water and wastewater testing were measured at different time intervals (Nicholson et al., 1983). For TOC measurement, the TOC analyzer device Jena model, made in Germany, was used. After determining the concentration of the above parameters, statistical analyzes were performed using Excel software and SPSS v.16.

The Biological Oxygen Demand 5 (BOD5) refers to the biological oxygen demand calculates over 5 days at $20^{\circ} \mathrm{C}$. Chemical Oxygen Demand. A value of the quantity of oxygen needed for chemical oxidation of organic material in water by a strong chemical oxidant (expressed in $\mathrm{mg} / \mathrm{L}$ ). COD is always equal to or higher than BOD since it is the total oxygen needed for perfect oxidation. 


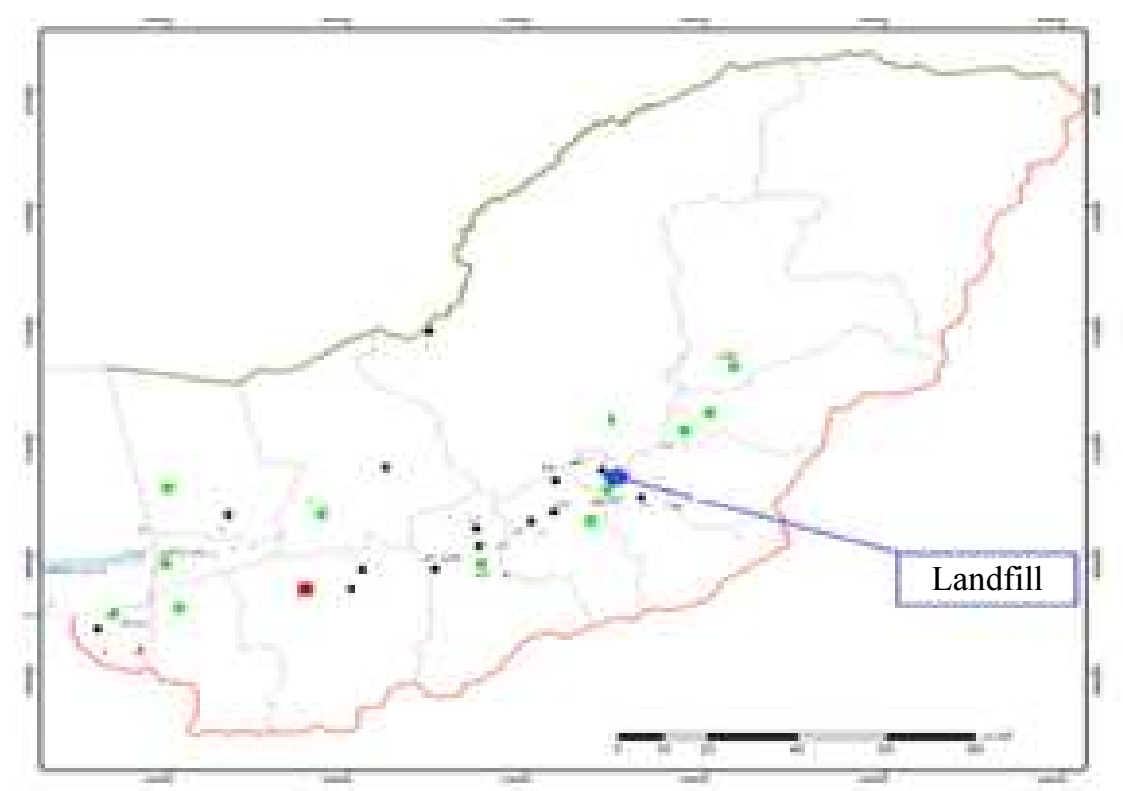

Fig. 1: Map of Golestan province and political divisions of cities

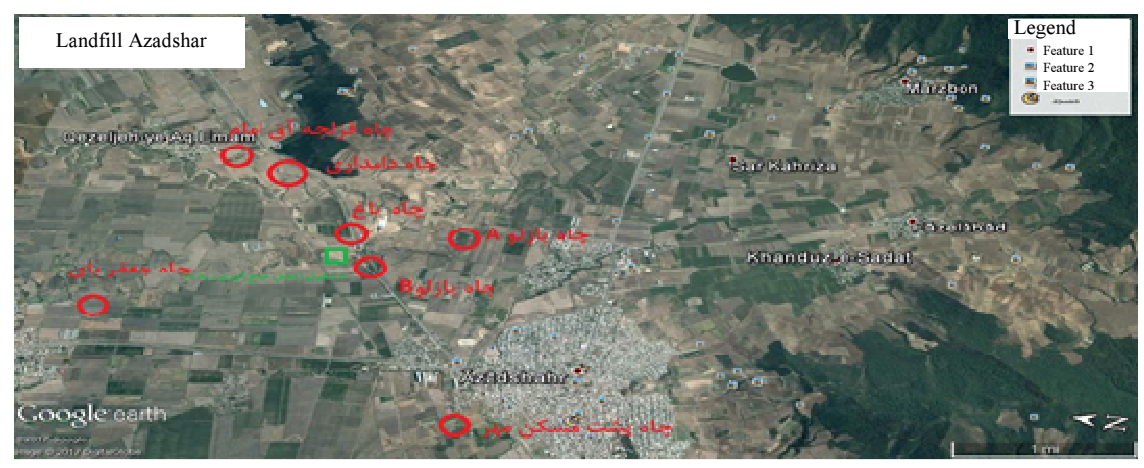

Fig. 2: Location of the Azadshahr city and water wells and landfills

Table 2: Well coordinates of the sample wells in the studied area

\begin{tabular}{lll}
\hline Row & Well location & Longtitudes/Latitudes \\
\hline 1 & Yazerllo Well upstream & $55.195606 / 37.102092$ \\
2 & Yazerlou Well upstream (top Asian road) & $55.191016 / 37.109760$ \\
3 & Jafarbay_downstream & $55.172692 / 37.132841$ \\
4 & Maskanemehr Well downstream & $55.164137 / 37.098530$ \\
5 & Ghezelieh Well downstream & $55.202913 / 37.125978$ \\
6 & Damdari Well downstream & $55.201769 / 37.120476$ \\
7 & Chahbagh (next to the landfill) & $55.188404 / 37.114216$ \\
\hline
\end{tabular}

Table 3: Variables measured in water tests

\begin{tabular}{|c|c|c|c|c|}
\hline Row & Variable & Type variable & Units & Measurement method \\
\hline 1 & $\mathrm{PH}$ & Quantitative-discrete & - & $\mathrm{Ph}$ metergauge \\
\hline 2 & TOC & Quantitative- Continuous & Ml & $\begin{array}{l}\text { Measured in accordance with the standard } \\
\text { method-TOC analyzer }\end{array}$ \\
\hline 3 & Hardness & Quantitative- Continuous & Mg.1 & Measured according to standard titration method \\
\hline 4 & Chloror & Quantitative- Continuous & Mg.1 & Measured according to standard titration method \\
\hline 5 & Temperature & Quantitative-discrete & Centgrade & thermometer \\
\hline
\end{tabular}


It is an indirect measure of the quantity of organic material present in water or wastewater: The more the organic content, the more oxygen is needed to chemically oxidize it (high COD). High organic content is commonly an indicator of water pollution. The COD reduced by the BOD gives a sign of the non-biodegradable chemicals and thus the toxicity of the water.

\section{Results}

Results of Parameters of TDS, chlorine, pH, Hardness and Water Temperature of Wells around Landfill

As shown in Fig. 3 and 4, the highest TDS is depicted for Damdari well downstream and the lowest goes for Yazerlow (A) well located in upstream with the amounts of 755 and 688 (mg.l) respectively (Fig. 3) and the highest chlorine goes for the Chaharbagh well in downstream and the lowest is related to the MaskaneMehr well in the downstream with the amounts of 85 and 23 (mg.l) (Fig. 4).

Table 1 shows categorization of groundwater by total soluble solids (T.D.S). It divides 3 groups of T.D.S (Fresh water, Water with medium salt, Salty water; 0 $<$ TDS $<35000$ ppm).

According to Fig. 5 and 6 , the highest hardness is related to Chahbagh wells in the downstream and the lowest goes for Damdari well in the upper hand with the amounts of 453 and $210 \mathrm{mg} \mathrm{l}$, respectively, considering $\mathrm{CaCO}_{3}$ (Fig. 5) and the highest EC is related Charbagh in downstream and the lowest is germane to Ghezalche well upstream and downstream with the values of 1694 and $1245 \mu \mathrm{s} . \mathrm{cm}$ (Fig. 6).
According to the following water temperature figures (Fig. 7) and PH (Fig. 8), the highest water temperature is related to the Jafarbay well downstream and the lowest for the Yazerlo well A located upstream with the values 20.5 and $18.8^{\circ} \mathrm{C}$, respectively (Fig. 7). However, the highest PH goes for Chahbagh well downstream and Ghezelje well with the values of 7.45 and 6.89 respectively.

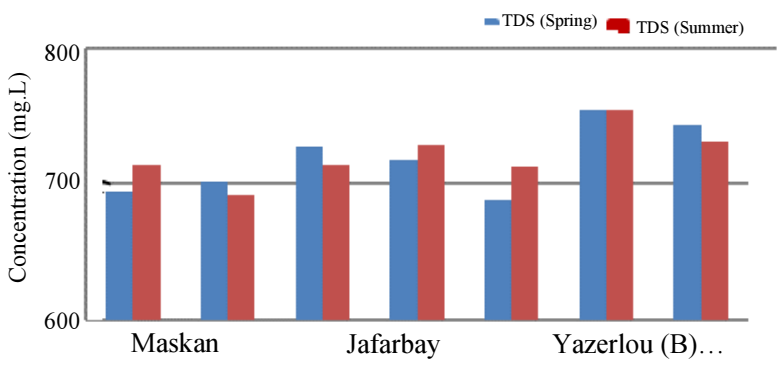

Fig. 3: Concentration diagram of TDS in the wells around landfill in the two seasons of spring and summer of 2017

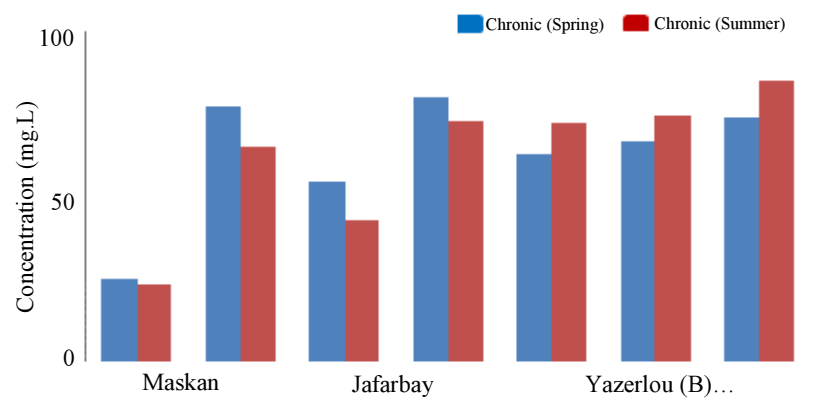

Fig. 4: Chlorine concentration diagram of the wells around landfill in two seasons of spring and summer of 2017

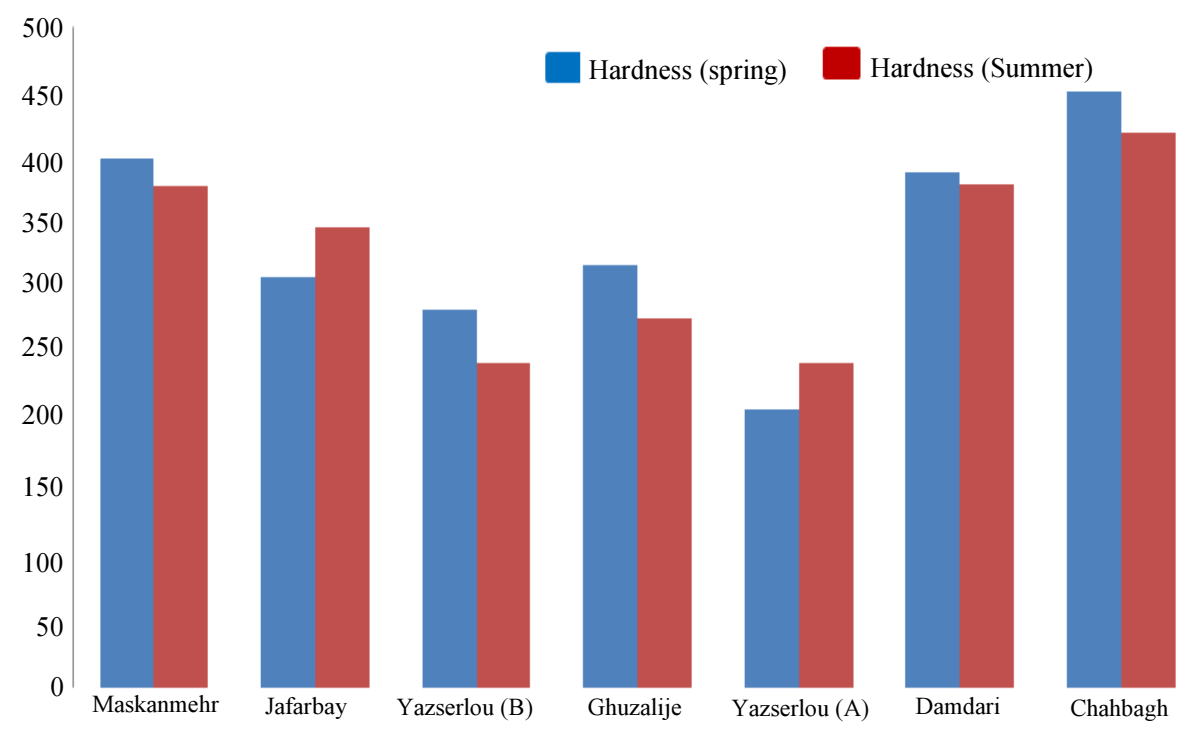

Fig. 5: Hardness concentration diagram of wells near landfills in two seasons of Spring and Summer $2017\left(\mathrm{mg}^{1} \mathrm{CaCO}_{3}\right)$ 


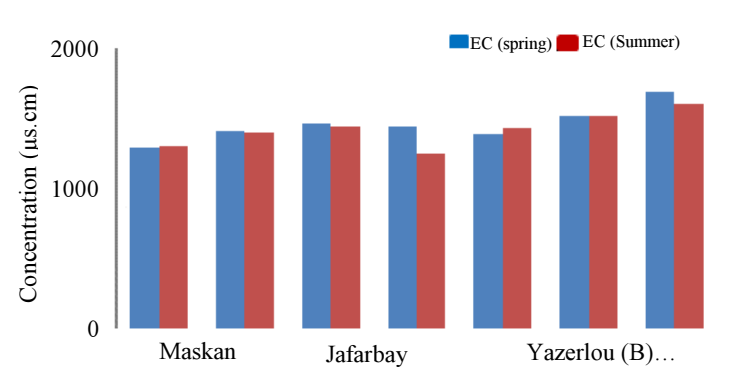

Fig. 6: EC values of wells around landfill in the spring and summer of $2017(\mu \mathrm{s} . \mathrm{cm})$

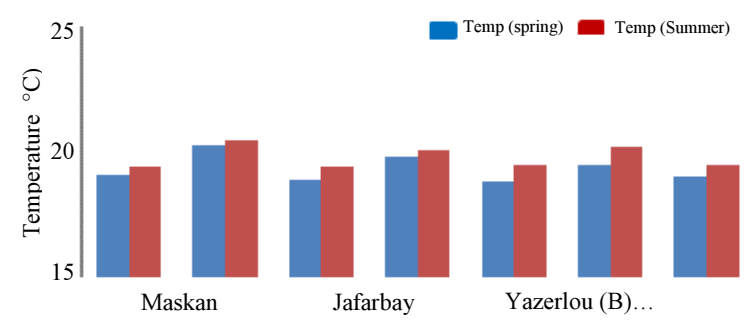

Fig. 7: Water temperature diagram of the wells around landfill in the two seasons of spring and summer 2017

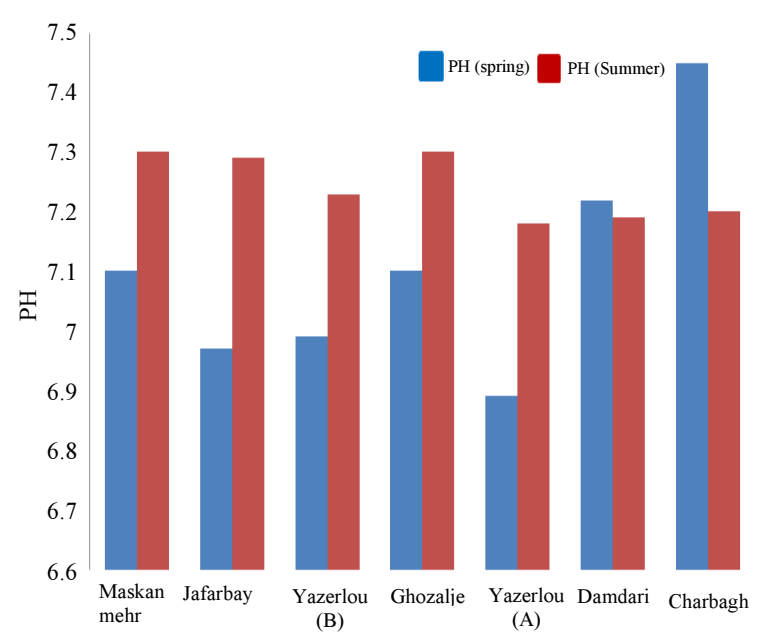

Fig. 8: PH diagram of the water wells around landfill in the two seasons of spring and summer of 2017

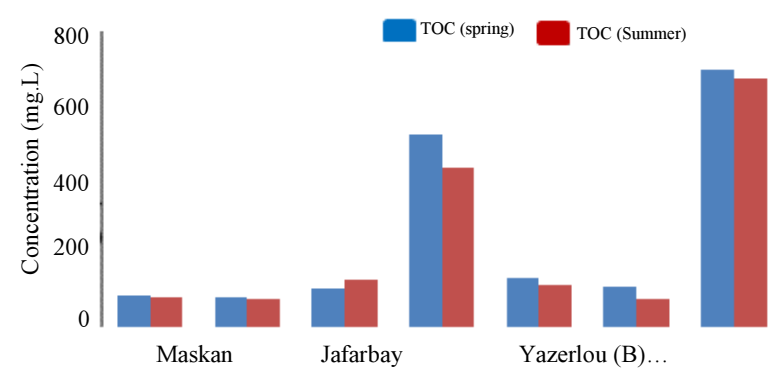

Fig. 9: TOC concentration chart (mg.l) of the wells around landfill in the spring and summer of 2017
Results of Concentration of Organic Carbon Particle (TOC) Characteristics of Water Wells around the Landfill

As shown in (Fig. 9), revealed that the highest TOC is for the Chahbagh well and the lowest TOC is for Damdari wells in downstream with the values of 735 and 75 (mg.l), respectively.

\section{The Statistical Results of the Difference in Total Water Quality Parameters of Downstream and Upstream Wells}

Based on the results of (Table 4), the TDS of water in the wells around landfill is $719 \pm 21$ (mg.l), which is not statistically different between spring and summer. the TDS for drinking water is equivalent to a maximum of 500 and a maximum permissible dose of 1500 (mg.l), in this regard water in the surrounding wells is considered in the permitted range. On the other hand, water chlorine in the wells near landfill is $62 \pm 9$ (mg.l) and there is no statistically significant difference between spring and summer. Chlorine levels for drinking water are equivalent to a maximum of 250 and a maximum permissible concentration of 400 (mg.l), considering that the chlorine content of wells is located in the permissible range. Also, the water hardness of the wells around landfill is $333 \pm 73$ (mg.l) $\mathrm{CaCO}_{3}$, which is not statistically different between spring and summer. According to the mentioned standard, the hardness for drinking water is equivalent to a medium of 200 and a maximum permissible concentration of 500 (mg.l), in terms of $\mathrm{CaCO}_{3}$, in this account hardness limit is within the permitted range. On the other hand, due to the significant increase in the level of water hardness of the downstream wells relative to the upstream wells, this could be the result of the penetration of emulsion into groundwater. So that, the increase in water hardness of wells in the infected wells with organic matter has been proved by other investigations (Mor et al., 2006). The EC water content was $1440 \pm 120$ ( $\mu$ s.cm), which is not statistically significant between spring and summer. According to 1053 countries and other regions of the world, no EC levels have been provided for drinking water. Therefore, comparisons cannot happen in this regard. However, since the amount of EC is in relation and correlation with TDS in this study, its increase could indicate an increase in other hazardous parameters. The water temperature of the wells near landfill is $19.5 \pm 0.5^{\circ} \mathrm{C}$, which is not statistically significant between spring and summer. The PH of the water in the wells near landfill is $7.1 \pm 0.15$, which is not statistically significant between spring and summer. According to the standard of 1053 countries, the $\mathrm{PH}$ of drinking water is equivalent to an optimal level of 6.5 to 8.5 . In this regard, PH level of the wells is within the permitted range. In another study carried out on wells near the landfill, the $\mathrm{PH}$ results were also 
within the permitted range (Jhamnani and Singh, 2009). The calculated TOC is $238 \pm 240^{\circ} \mathrm{C}$, which is not statistically different between spring and summer. According to the standard of 1053 countries, there is no standard level of TOC for drinking water. Surely, Kawamura has set the maximum allowable TOC to enter the treatment plant as $4(\mathrm{mg} .1)$, with which the values of these wells are much higher than the limit. However, there is not a remarkable statistical difference between the TOC water content in upstream and downstream wells, but its value in downstream wells is about 2.5 times higher than the upstream wells, which can be due to the penetration of organic matter into the groundwater. Jhamnani and Singh (2009) reported high levels of organic carbon (DOC) in water in the landfill area (Mor et al., 2006).

Figure 3 shows condensation drawing of TDS in the pits around landfill in the two seasons of spring and summer of 2017 and it divides 3 zones for condensation Maskan, Jafarbay, Yazerlou, Respectively. The most significance TDS Is YazerLou rather than another. The most concentration is almost 750 for Yazerlou and the least concentration is close to 680 for spring. But the trend of TDS is a substantial increase. Figure 4 displays Chlorine condensation drawing of the pits around landfill in two seasons of spring and summer of 2017. It shows the least of concentration Chlorine in Maskan (Spring and Summer) but another of the concentration Chlorine have a gradually trend. Figure 5 shows hardness condensation drawing of pits near landfills in two seasons of Spring and Summer 2017 (mg.l) that at first trend of figure decreases dramatically and it suddenly increases to $450 \mathrm{mg} . \mathrm{l}$. In Yazerlou have a decreation of condensation of Hardness (200 mg.l for Spring, $230 \mathrm{mg}$.l for Summer). Figure 6 shows EC worths of pits around landfill in the spring and summer of 2017. The trend is gradually increased from Maskan to Yazerlou but the highest EC is almost 1900 in
Yazerlou (Spring) and it shows Yazerlou is an important zone which it should be considered rather than other zones. Figure 7 illustrate Water temperature drawing of the pits around landfill in two seasons of Spring and Summer 2017. The trend fluctuates during the period (Summer and spring) but the highest temperature is almost 20 (Maskan, Summer). Figure 8 demonstrates PH drawing of the water pits around landfill in the two seasons of Spring and Summer 2017. It divides 7 zones that Charbagh has the largest PH is nearly 7.5 (Spring) but the least $\mathrm{PH}$ is almost 6.9 In Yazerlou (Spring). Figure 9 shows the TOC condensation chart of the pits around landfill in the Spring and Summer of 2017. Yazerlou has the largest condensation is almost 800 (Spring). Although Jafarbay has one highest amount of TOC are almost 500 and 400, respectively. Another result has a substantial decrease in TOC.

\section{Investigation of the Effect of Landfill on Physicochemical Parameters of Water in Downstream and Upstream Wells}

The average values of physicochemical parameters of water (Table 4) and independent t-test (Table 5) between upstream and downstream wells on the effects of landfill on water quality parameters showed that the average of all 7 parameters measured in wells in downstream wells of the landfill is higher than the upstream wells, but statistically speaking, only the water hardness parameter of the upstream and downstream wells has a significant difference. This means that landfill has increased the water hardness of the downstream wells. The hardness of underground water contaminated with organic matter has been proven by other studies (Mor et al., 2006; Jhamnani and Singh, 2009). Also, the results revealed that there was no significant difference between water physicochemical parameters including TDS, chlorine, hardness, EC, temperature, $\mathrm{PH}$ and TOC of all wells in spring and summer.

Table 4: Physicochemical parameters of water in upstream and downstream wells of the landfill

\begin{tabular}{|c|c|c|c|c|c|c|c|c|}
\hline Solids & & $\begin{array}{l}\text { Carbon organic } \\
\text { matter (mg.l) }\end{array}$ & $\mathrm{PH}$ & Temperature & $\begin{array}{l}\text { Electrical } \\
\text { conductivity }(\mu \mathrm{s} . \mathrm{cm})\end{array}$ & $\begin{array}{l}\text { Hardness } \\
(\mathrm{mg} .1)\end{array}$ & $\begin{array}{l}\text { Chlorine } \\
\text { (mg.l) }\end{array}$ & $\begin{array}{l}\text { Total soluble } \\
\text { (mg.l) }\end{array}$ \\
\hline \multirow[t]{5}{*}{ Up stream } & Mean & 118.65 & 7.070 & 19.150 & 1432.75 & 246.75 & 58.12 & 710.50 \\
\hline & $\mathrm{N}$ & 4.00 & 4.000 & 4.000 & 4.00 & 4.00 & 4.00 & 4.00 \\
\hline & Std & 13.14 & 0.150 & 0.351 & 31.41 & 31.06 & 12.45 & 16.29 \\
\hline & Min & 10.35 & 6.900 & 18.800 & 1389.00 & 210.00 & 43.00 & 688.00 \\
\hline & Max & 13.28 & 7.200 & 19.500 & 1464.00 & 286.00 & 72.20 & 727.00 \\
\hline \multirow[t]{5}{*}{ Down stream } & Mean & 286.50 & 7.220 & 19.740 & 1443.50 & 368.20 & 64.39 & 723.20 \\
\hline & $\mathrm{N}$ & 10.00 & 10.000 & 10.000 & 10.00 & 10.00 & 10.00 & 10.00 \\
\hline & Std & 273.61 & 0.139 & 0.518 & 142.95 & 53.29 & 22.05 & 23.17 \\
\hline & Min & 75.00 & 7.000 & 19.000 & 1245.00 & 280.00 & 23.00 & 692.00 \\
\hline & Max & 735.00 & 7.500 & 20.500 & 1694.00 & 453.00 & 85.00 & 755.00 \\
\hline \multirow[t]{5}{*}{ Total } & Mean & 238.54 & 7.170 & 19.570 & 1440.35 & 333.50 & 62.60 & 719.57 \\
\hline & $\mathrm{N}$ & 14.00 & 14.000 & 14.000 & 14.00 & 14.00 & 14.00 & 14.00 \\
\hline & Std & 240.96 & 0.152 & 0.530 & 120.01 & 73.69 & 19.52 & 21.64 \\
\hline & Min & 75.00 & 6.900 & 18.800 & 1245.00 & 210.00 & 23.00 & 688.00 \\
\hline & Max & 735.00 & 7.500 & 20.500 & 1694.00 & 453.00 & 85.00 & 755.00 \\
\hline
\end{tabular}


Sara Abdollahi et al. / American Journal of Engineering and Applied Sciences 2019, 12 (2): 136.146 DOI: 10.3844/ajeassp.2019.136.146

Table 5: Independent $t$ test for water parameters in upstream and downstream wells in landfill

\begin{tabular}{|c|c|c|c|c|c|c|c|}
\hline Parameter & $\mathrm{t}$ & $\mathrm{df}$ & Sig (2-tailoed) & $\begin{array}{l}\text { Mean } \\
\text { difference }\end{array}$ & $\begin{array}{l}\text { Std Error } \\
\text { difference }\end{array}$ & $\begin{array}{l}95 \% \text { C.I. } \\
\text { Lower }\end{array}$ & Uper \\
\hline Total soluble solid & -0.991 & 12 & 0.341 & -12.700 & 12.810 & -40.621 & 15.221 \\
\hline Chlorine & -0.527 & 12 & 0.608 & -6.260 & 11.880 & -32.165 & 19.635 \\
\hline Hardness & -4.216 & 12 & 0.001 & -121.450 & 28.800 & -184.220 & -58.679 \\
\hline EC & -0.149 & 12 & 0.884 & -11.000 & 73.830 & -171.861 & 149.861 \\
\hline Temperature & -2.067 & 12 & 0.061 & -0.590 & 0.285 & -1.211 & 0.031 \\
\hline $\mathrm{PH}$ & -1.721 & 12 & 0.111 & -0.145 & 0.084 & -0.328 & 0.038 \\
\hline Carbon organic (mg.l) & -1.197 & 12 & 0.254 & -167.8500 & 140.240 & -473.410 & 137.710 \\
\hline
\end{tabular}

Table 6: Spearman correlation test among all water quality parameters of wells

\begin{tabular}{|c|c|c|c|c|c|c|c|}
\hline \multirow{2}{*}{$\frac{\text { Parameter }}{\text { Total soluble solids (mg.l) }}$} & \multicolumn{2}{|c|}{ Total soluble solids } & \multirow[t]{2}{*}{ Chlorine } & \multirow[t]{2}{*}{ Hardness } & \multirow[t]{2}{*}{ EC } & \multirow[t]{2}{*}{ Temperature } & \multirow[t]{2}{*}{ PH } \\
\hline & Cor & 1.000 & & & & & \\
\hline & Sig & & & & & & \\
\hline & $\mathrm{N}$ & 14.000 & & & & & \\
\hline \multirow[t]{3}{*}{ Chlorine (mg.l) } & Cor & 0.433 & 1.000 & & & & \\
\hline & Sig & 0.122 & & & & & \\
\hline & $\mathrm{N}$ & 14.000 & 14.000 & & & & \\
\hline \multirow[t]{3}{*}{ Hardness (mg.l) } & Cor & 0.488 & 0.248 & 1.000 & & & \\
\hline & Sig & 0.076 & 0.392 & & & & \\
\hline & $\mathrm{N}$ & 14.000 & 14.000 & 14.000 & & & \\
\hline \multirow[t]{3}{*}{ Electrical conductivity $(\mu \mathrm{s} . \mathrm{cm})$} & Cor & 0.691 & 0.521 & 0.455 & 1.000 & & \\
\hline & Sig & 0.006 & 0.056 & 0.102 & & & \\
\hline & $\mathrm{N}$ & 14.000 & 14.000 & 14.000 & 14.000 & & \\
\hline \multirow[t]{3}{*}{ Temperature } & Cor & 0.093 & 0.524 & 0.062 & -0.053 & 1.000 & \\
\hline & Sig & 0.752 & 0.055 & 0.834 & 0.857 & & \\
\hline & $\mathrm{N}$ & 14.000 & 14.000 & 14.000 & 14.000 & 14.000 & \\
\hline \multirow[t]{3}{*}{ PH } & Cor & 0.369 & 0.005 & 0.392 & 0.081 & 0.246 & 1.000 \\
\hline & Sig & 0.149 & 0.988 & 0.166 & 0.782 & 0.397 & \\
\hline & $\mathrm{N}$ & 14.0000 & 14.000 & 14.000 & 14.000 & 14.000 & 14.000 \\
\hline \multirow[t]{3}{*}{ Carbon organic matter } & Cor & 0.253 & 0.396 & 0.011 & 0.308 & -0.361 & 0.063 \\
\hline & Sig & 0.382 & 0.161 & 0.970 & 0.284 & 0.205 & 0.829 \\
\hline & $\mathrm{N}$ & 14.000 & 14.000 & 14.000 & 14.000 & 14.000 & 14.000 \\
\hline
\end{tabular}

Table 7: Spearman Test among water quality parameters of the wells at a distance from landfill

\begin{tabular}{|c|c|c|c|c|c|c|}
\hline Parameter & & Space & $\begin{array}{l}\text { Total } \\
\text { soluble solids }\end{array}$ & Chlorine & Hardness & $\begin{array}{l}\text { Electrical } \\
\text { conductivity }\end{array}$ \\
\hline \multirow[t]{3}{*}{ Space } & Cor & 1.000 & & & & \\
\hline & Sig & & & & & \\
\hline & $\mathrm{N}$ & 10.000 & & & & \\
\hline \multirow[t]{3}{*}{ Total soluble solids (mg.l) } & Cor & -0.830 & 10.000 & & & \\
\hline & Sig & 0.001 & & & & \\
\hline & $\mathrm{N}$ & 10.000 & 10.000 & & & \\
\hline \multirow[t]{3}{*}{ Chlorine (mg.l) } & Cor & -0.434 & 0.318 & & & \\
\hline & Sig & 0.105 & 0.138 & & & \\
\hline & $\mathrm{N}$ & 10.000 & 10.000 & 10.000 & & \\
\hline \multirow[t]{3}{*}{ Hardness (mg.l) } & Cor & -0.626 & 0.370 & -0.018 & 1.000 & \\
\hline & Sig & 0.027 & 0.147 & 0.480 & & \\
\hline & $\mathrm{N}$ & 10.000 & 10.000 & 10.000 & 10.000 & \\
\hline \multirow[t]{3}{*}{ Electrical conductivity $(\mu \mathrm{s} . \mathrm{cm})$} & Cor & -0.756 & 0.661 & 0.600 & 0.624 & \\
\hline & Sig & 0.006 & 0.019 & 0.033 & 0.027 & \\
\hline & $\mathrm{N}$ & 10.000 & 10.000 & 10.000 & 10.000 & 10.000 \\
\hline \multirow[t]{3}{*}{ 10Carbonaceous material (mg.l) } & Cor & -0.582 & 0.273 & 0.442 & 0.345 & 0.370 \\
\hline & Sig & 0.039 & 0.223 & 0.100 & 0.164 & 0.147 \\
\hline & $\mathrm{N}$ & 10.000 & 10.000 & 10.000 & 10.000 & 10.000 \\
\hline
\end{tabular}




\section{Correlation Test of Physicochemical Parameters of Water in Wells around Landfill}

Table 6 shows the results of Spearman's correlation test between the water quality parameters of all wells. There is a meaningful relationship between parameters of EC-TDS. This is a positive relationship, which means that the increase in EC has increased TDS and vice versa.

Investigating the Effect of the Distance of Wells to Landfill on Water Quality Parameters of Downstream Wells

The Spearman test results show a significant relationship between the water quality parameters of the lower wells at a distance from the landfill. There is a significant relationship between the physicochemical parameters of water including TDS, hardness, EC and TOC with distance from landfill in downstream wells. By increasing the distance between the wells from Landfill, the numerical values of these parameters have been increased (Table 7).

\section{The Results of the Statistical Difference between the Quality Parameters of Well Water in Spring and Summer}

The total values of the physicochemical parameters of upstream and downstream groundwater wells in spring and summer are shown in the Table 8 and 9.
The results indicate that there is no significant difference between the values of physicochemical parameters of water including TDS, chlorine, hardness, EC, temperature, $\mathrm{PH}$ and TOC in all wells in spring and summer.

\section{Discussion}

The results of this study indicate that the concentration of physicochemical parameters of water wells near landfill is below the standard level for drinking water of the country. Although the standard amount of TOC is not determined for water, its value is high based on what the scientific books offered. The concentration of all of the quality parameters in the downstream wells was measured more than the upstream wells, but with the exception of the hardness parameter, there was no significant relationship among other parameters. Since Azadshahr is known as an agricultural area, the pollution of underground water used in agriculture can lead to the transfer of pollutants to human beings. Therefore, careful solutions should be taken to prevent underground water pollution in the area.

Table 6 shows the Spearman relation experiment among all water modality variables of pits. It divides 7 components (Total Soluble Solids, Chlorine, Hardness, $\mathrm{EC}$, temperature, $\mathrm{PH}$ ) that regard the tables one of them efficiency application of the result of water quality.

Table 8: Average values of physicochemical parameters of water in the wells around landfill in two seasons

\begin{tabular}{lllccc}
\hline Parameter & Season & $\mathrm{N}$ & Mean & Std Deviation & Std Error Mean \\
\hline Total soluble solids (mg.l) & Spring & 7 & 718.00 & 24.946 & 9.428 \\
& Summer & 7 & 721.142 & 19.675 & 7.436 \\
Chlorine (mg.l) & Spring & 7 & 62.985 & 18.968 & 7.169 \\
& Summer & 7 & 62.214 & 21.587 & 8.159 \\
Hardness (mg.l) & Spring & 7 & 338.428 & 81.616 & 30.848 \\
Elecrical conductivity $(\mu$ s.cm) & Summer & 7 & 328.571 & 71.053 & 26.855 \\
& Spring & 7 & 1460.571 & 123.648 & 46.734 \\
temperature & Summer & 7 & 1420.142 & 122.323 & 46.234 \\
& Spring & 7 & $19.342 / 19$ & 0.550 & 0.208 \\
PH & Summer & 7 & $19.8 / 19$ & 0.454 & 0.171 \\
& Spring & 7 & 7.114 & 0.195 & 0.073 \\
Carbonaceous material $(m g .1)$ & Summer & 7 & 7.242 & 0.053 & 0.020 \\
& Spring & 7 & 252.942 & 264.640 & 100.024 \\
\hline
\end{tabular}

Table 9: Independent t-test between water parameters in landfill wells between two seasons

\begin{tabular}{lllllrrr}
\hline & \multicolumn{3}{c}{$\begin{array}{l}\text { Degrees } \\
\text { of freedom }\end{array}$} & \multicolumn{1}{c}{ Sig } & \multicolumn{1}{c}{$\begin{array}{l}\text { Difference } \\
\text { Mean }\end{array}$} & Std Error & \multicolumn{2}{c}{ Lower C Interval } & Upper \\
\hline Total soluble solids (mg.l) & \multicolumn{1}{c}{-0.262} & 12 & 0.798 & -3.14 & 12.000 & -29.30 & 23.020 \\
Chlorine (mg.l) & 0.071 & 12 & 0.945 & 0.77 & 10.860 & -22089.00 & 24.430 \\
Hardness (mg.l) & 0.241 & 12 & 0.814 & 9.85 & 40.900 & -79.25 & 98.970 \\
EC $(\mu$ s.cm) & 0.615 & 12 & 0.550 & 40.42 & 65.730 & 102.80 & 183.660 \\
Temperature & -1.694 & 12 & 0.116 & -0.45 & 0.260 & -1.04 & 0.130 \\
PH & -1.681 & 12 & 0.119 & -0.12 & 0.076 & -0.29 & 0.038 \\
Carbon material (mg.l) & 0.215 & 12 & 0.833 & 28.80 & 133.800 & -262.72 & 320.320 \\
\hline
\end{tabular}


Table 7 displays the Spearman experiment among water modality components of the pits at a distance from the landfill. the least amount of parameters are 0.001, $0.27,0.006,0.039$ for Total Soluble Solids, Hardness, Electrical Conductivity, carbonaceous material, respectively. Table 8 shows the mean worth's of physicochemical components of water in the pits around landfill in two seasons. It displays that Electrical Conductivity is the highest mean and $\mathrm{PH}$ is the least mean. it is obvious EC, TDS, Hardness, Carbonaceous are more important than other parameters. Table 9 shows Independent t-test between water components in landfill pits between two seasons. it is also explicit EC, TDS, Hardness, Carbonaceous are more significant than other components.

\section{Conclusion}

It also expands and enlarges recent, commonly appropriate symptomatic procedures for contamination original recognition. notions dealing with landfill place and plan are introduced in conclusion. Groundwater specimens were prepared from landfill-zone and its next zone to review the possible effect of leachate infiltration on groundwater modality. Our examination prepares a quantitative overview of the main activities to happen in this pollution method. Places close to landfills have a lot of possibilities for pollution of groundwater since there is a great possibility for pollution with latex in these zones. In this article, the modality of physic-chemical and carbon-organic substances of water pits around landfill of Azad-Shahr town was checked. To perform this aim, polling of water from seven deep pits around the landfill zone (upstream and downstream of the inhumation zone) was carried out in the spring and summer of 2017. As well as, the consequences displayed that the condensation of physicochemical variables of water wells around landfill is beneath the criteria level of the drinking water of the country and the condensation of all the modality variables in lower wells was computed more than great wells. But for the difficulty variable, there was no considerable correlation with other variables.

\section{Acknowledgment}

This research was supported by the Isfahan University of the Technology. We thank our all authors who provided insight and expertise that greatly assisted the research.

\section{Author's Contributions}

All authors contributed to design the study, write and revise the manuscript.

\section{Ethics}

The present Study and ethical aspect were approved by the Isfahan University of the Technology. The present study was approved by the Isfahan University of Technology.

\section{References}

Abbasi, S., K. Mohammadi, M. Kholghi and K. Harward, 2013. Aquifer vulnerability assessments using DRASTIC, Weights of Evidence and the Analytic Element Method. Hydrol. Sci. J., 58: 186-197. DOI: 10.1080/02626667.2012.743027

Abedi Kopae, G., 2001. Effect of Mashhad landfill on groundwater resource pollution. Proceedings of the 4th National Conference of Environmental Health, Nov. 15-17; Tehran, Iran

Badou, K., 2000. An overview on the design principles of sanitary landfills-urban waste engineering (landfills), School of Public Health, Tehran University of Medical Sciences, Tehran, Iran. Proceedings of the 3rd National Conference on Environmental Health, (CEH' 00) pp: 294-303.

Borden, R.C. and T.M. Yanoschak, 1990. Ground and surface water quality impacts of North Carolina sanitary landfills. Water Resources Bull., 26: 26092617. DOI: $10.1111 /$ j.1752-1688.1990.tb01370.x

Boyd, C.E. and C.S. Tucker, 2014. Handbook for Aquaculture Water Quality.

Burton, G.A. and J.R. Robert Pitt, 2014. Stormwater Effects Handbook: A Toolbox for Watershed Managers, Scientists and Engineers. 1st Edn., Lewis Publishers, pp: 928.

Dehkordi, A.M., 2004. A survey effect of steel industry wastewater lagoon on chemical groundwater quality and around. MSc Thesis, Health Colleage, Isfahan.

Eaton, A.D. and M.A.H. Franson, 2005. Association AWW, Federation WE. Standard Methods for the Examination of Water and Wastewater. 1st Edn., American Public Health Association, pp: 1368.

Filipic, M., 1995. Mutagenicity and toxicity of water extracts from the Sora river area. Mutat. Res./Genetic Toxicol., 342: 1-8. DOI: $10.1016 / 0165-1218(95) 90084-5$

Hasheminezhad, H. and A. Karimi, 2006. Investigation on the quality of groundwater quality in Najaf-Abad and Isfahan hydraulic units. Proceedings of the 1st Regional Conference on Optimal Utilization of Water Resources in Karoun and Zayandehrud Fields, (KZF' 06), Shahrekord University, pp: 1829-1839.

Jamshidi, A., A. Tajamiri and S.A. Mirbagheri, 2014. Investigating the effect of landfill site landfill in Yasuj city on the quality of downstream water source (well No. 6). J. Yasuj Univ. Med. Sci., 19: 347-360. 
Jhamnani, B. and S.K. Singh, 2009. Groundwater contamination due to Bhalaswa landfill site in New Delhi. Int. J. Civil Environ. Eng., 3: 181-185.

Kreith, F. and G. Tchobanoglous, 2002. Handbook of Solid Waste Management. 2nd Edn., McGraw-Hill Professional, New York.

Mor, S., K. Ravindra, R.P. Dahiya and A. Chandra, 2006. Leachate characterization and assessment of groundwater pollution near municipal solid waste landfill site. Environ. Monit. Assess. J., 118: 435-456. DOI: $10.1007 / \mathrm{s} 10661-006-1505-7$

Nagarajan, R., S. Thirumalaisamy and E. Lakshumanan, 2012. Impact of leachate on groundwater pollution due to non-engineered municipal solid waste landfill sites of erode city, Tamil Nadu, India. Iran. J. Environ. Health Sci. Eng., 9: 35-40. DOI: $10.1186 / 1735-2746-9-35$

Nasrabadi, T. and P.A. Maedeh, 2014. Groundwater quality degradation of urban areas (case study: Tehran city, Iran). Int. J. Environ. Sci. Technol., 11: 293-302. DOI: 10.1007/s13762-013-0340-y

Nicholson, R.V., J.A. Cherry and E.J. Reardon, 1983. Migration of contaminants in groundwater at a landfill: A case study. J. Hydrol., 63: 131-176. DOI: 10.1016/0022-1694(83)90226-3

Nixon, B., R.J. Murphy and R.I. Stessel, 1997. An empirical approach to the performance assessment of solid waste landfills. London, Royaume-Uni, Sage of local hydrogeology on natural attenuation of leachate at a municipal landfill. Int. J. Environ. Sci. Technol., 4: 133-140.
Osilan, K.S., 2016. Effect of water deficit stress on the content of soluble sugars, proline, leafy vegetable and grain protein in some sunflower hybrids (Helianthus annuus L). Iran. J. Field Crop Sci., 47: 175-184.

Pishkar Dehkordi, A.R., 2004. Survey the possible effects of industrial wastewater disposal lagoon steel on groundwater chemical quality of the surrounding. MSc Thesis, School of health, Isfahan University of Medical Sciences.

Shariat Panahi, M., 1998. Principle of Quality and Treatment of Water and Waste Water. 5th Edn., Tehran University Press, Tehran.

Sholichin, M., 2012. Field investigation of groundwater contamination from solid waste landfill in Malang, Indonesia. Int. J. Civil Environ. Eng., 12: 74-81.

Sládecek, V., 1973. System of water quality from the biological point of view. Int. Rev. Hydrobiol.

Voutchkov, N., 2014. Desalination Engineering: Operation and Maintenance. 1st Edn., McGraw-Hill Education, ISBN-10: 0071804226, pp: 336.

Zoghi, M.J. and A. Ghavidel, 2010. Application of HELP model for estimating the amount of production latex in the Trash Basin (case study: Semnan Landfill). Health Environ. Magazine, 4: 65-76. 